\title{
REVIEW OF DIASPORA THEORY AND TRANSNATIONALISM BY HIMADRI LAHIRI
}

\author{
AURITRA MUNSHI \\ Raiganj University, West Bengal \\ auritram@gmail.com
}

Received: $17-10-2019$

Accepted: 07-01-2020

\begin{abstract}
(c) (i)
Critical writings on diasporic literary works constitute a large corpus. However, the number of theoretical works on the phenomenon called diaspora is relatively small. Most of the works belonging to the latter category focus either on a particular discursive aspect (such as ethnicity, hybridity, and assimilation) or on a distinct ethnicity or community (such as the Jews, the Hindus or the South Asians, Africans and Mexicans). There are only a handful of books which provide a holistic view of diaspora theory as it has evolved over the last few decades. Some of the books that have attempted to do so include Sudesh Mishra's Diaspora Criticism (2006), Jana Evans Braziel's Diaspora: An Introduction (2008), Robin Cohen's Global Diasporas: An Introduction (2010) and Diasporas: Concepts, Intersections, Identities (2010) edited by Kim Knott and Séan McLoughlin. In the meantime, new transnational refugee movements have taken place in different parts of the world and these have led to socio-political developments and generated significant debates. The main contribution of the book under review is that it covers the new geo-political realities and intervenes in the debates and discourses on the recent refugee movements (such as those of Syrian refugees and Rohingyas from Myanmar), thereby updating diaspora theories.
\end{abstract}

Himadri Lahiri's book Diaspora Theory and Transnationalism (2019) which is published by Orient Blackswan under the series title "Literary/Cultural Theory" consists of five wellresearched chapters with a preface by Allen Hibbard. The book covers the aspects traditionally discussed in diaspora studies such as race, gender, ethnicity, generation, homeland and hybridity, but takes particular care to include discussions on issues like citizenship and religion which have assumed immense importance in view of the global rise of rightwing politics and the enveloping environment of Islamophobia. In the introductory 
chapter Lahiri attempts to outline the importance of diaspora theory and transnationalism in the context of the contemporary situation when the global man-capital flow impacts upon individual lives and policies of nation-states. In fact, Lahiri, focuses on a dynamic relationship between subjects, and 'home' and 'host' country in the diasporic context. He defines 'diaspora' and 'transnationalism' and in the process cites the concepts of major theoreticians. In fact, Lahiri debunks the homeland/hostland binary in order to suggest that the concepts of 'hostland' as 'homeland' and of multiple 'homelands' have already emerged. Particularly important is his discussion of the differences between diaspora and transnationalism, and his identification of different stages in the development of diaspora theory.

In the next chapter, Lahiri provides a historical survey of different migratory movements right from the classical age upto modern times. He divides the modern phase into the early modern phase and late (contemporary) modern phase and discusses the role of colonialism and capitalism in generating large-scale movements of people. In this respect, he particularly mentions the forced migrations of Black people as slaves and the 'coolie diaspora' (after the official abolition of slavery). The term 'coolie diaspora' (which is also known as 'girmit diaspora') refers to the indentured labourers' journey to countries such as Fiji, Guyana, and the Caribbean Island. The indentured labourers were treated merely as a means of production. Lahiri cites works by Brij V. Lal (On the Other Side of Midnight) and Gaiutra Bahadur (Coolie Woman) which bring out the specific dynamics of the migration of the 'coolies' who were poor and mostly illiterate. Lahiri also mentions the 'cyber coolies' of contemporary times. Members of this class, motivated by upward social movement and lured by the 'American dream,' moved abroad voluntarily. Such migrant individuals, as Lahiri argues, may suffer from nostalgia, and may even attempt to form ethnic enclaves in the host countries. They try to reinscribe an imagined 'homeland' in the hostland, thereby challenging the very foundation of cartographical epistemology based on the concept of a single nation.

Lahiri in Chapter 2 focuses on the questions of generation, hybridity and citizenship in the context of diaspora and transnationalism. The first generation immigrants often tend to adopt a ghetto mentality. But Lahiri explains the significance of cultural hybridity in the multicultural context. He refers to Salman Rushdie's Imaginary Homeland in which Rushdie lambasts the ghetto mentality as 'a dangerous pitfall' (1991:19). Lahiri emphasises the role of generation in respect of acculturation and assimilation and in this context refers to the 
Japanese Americans who coined generational terms such as issei, nisei and sansei which refer to first, second and third generation members of the Japanese American community respectively. He traces generational conflicts latent in diasporic situations and justifies his point by referring to Jhumpa Lahiri's novel The Namesake and short story "When Mr Pirzada Came to Dine." Lahiri then focuses on the citizenship question and mentions the recent influx of refugees (such as Rohingya Muslims, Syrians, Hajong and Chakma) which raises debates about whether to offer them 'hospitality' and citizenship. He also discusses in some detail President Donald Trump's attitude to the economic refugees from Mexico and his insistence on building walls along the US-Mexican border. Lahiri in this respect seems to be more interested in the humanitarian concerns like hospitality than in technicalities of 'legal' and 'illegal' immigration.

Lahiri deals with gender and sexuality in the third chapter. He explains how 'gender' is an important consideration in the formulation of state policies in the host country mainly because of women's reproductive capacity. He in this respect refers to the United States, the United Kingdom and Israel which formulated anti-women racist immigration laws while formulating immigration policies at different points of time(2019:80-84). He also embarks on a discussion of the concepts of masculinity/femininity and queerness in the context of power relations in the diasporic space. Lahiri exhibits how masculinity/femininity is produced in coercive political and economic systems and how emasculation was imposed upon black bodies during the period of slavery. Drawing cues from various diasporic writers like Bharati Mukherjee and Manjushree Thapa, Lahiri then seeks to track down the possibilities of women's emancipation in the diasporic space as they legitimise their participation in the public domain. In this chapter Lahiri also dwells on queerness at length. Being a marker of alternative identity, queerness resists the creation of boundaries. Lahiri identifies points of intersections between queerness and diaspora: queerness is tied to the demolition of gender normativity which is better achieved in diaspora; diaspora too problematises the stability of geographic and national boundaries.

The role of religion in diaspora is an important area for critical discussion. Lahiri analyses this in the fourth chapter of his book. Religion, he argues, acts as a cementing agent that helps form a cohesive community in the difficult, unfamiliar diasporic space. He shows how religious practices are transmuted as the communities negotiate the new cultural and political space. Lahiri refers to Mohja Kahf's novel The Girl in the Tangerine Scarf which shows how 
Islamic practices go through transformations in the diaspora. Performing each ethno-cultural and religious rituals in a foreign territory may create animosity among the members of dominant communities. Lahiri could have mentioned in this connection Amartya Sen's book Identity and Violence which advocates that plurality of cultural ethos should not lapse into 'plural monoculturalism' (2003:156) which, according to Sen, creates ethnic boundaries and thus hinders interculturalism. Purkayastha's essay "Transgressing the Sacred-Secular, Private-Public Divide" which demonstrates how the authenticity of Hindu ritualistic performance of the Durga Puja goes through radical changes. The Hindu festival of Durga Puja, as Purkayastha points out, is performed even in church halls in the United Kingdom.

In order to demonstrate how a diasporic literary text can be read keeping in mind the various aspects mentioned earlier, Lahiri analyses Monica Ali's novel Brick Lane in Chapter 5. He brings out how the aspects of citizenship, generation, gender, and religion are embedded in Ali's work which is set against the background of the Brick Lane area of East London. It is a locality largely inhabited by immigrants from Bangladesh.

In the concluding chapter Lahiri takes up cyber communication to suggest that technology provides a new trajectory to the phenomenon called diaspora and transnationalism. In fact, the geopolitical barrier between local and global has been largely dissolved by means of telecommunication and mass media, which contribute to the mobilisation of political initiatives. Lahiri shows how internet evolves as a third space where diasporic activism is sucked into. He talks about the role of ethnic media in creating an ethnic solidarity through electronic communication in the diasporic space. He refers to the case of the Tibetan diaspora in particular to show how Tibetans keep in touch with one another through cyberspace. He touches upon the importance of mobility, networking, political activism, flows of ideas, images and currency. He suggests that the field of Diaspora and Transnational Studies will keep on altering its shapes in response to the changing socio-cultural and political contexts.

The book, a brilliant theoretical project, has been written with care and in a lucid language. It will encourage more discussions on the issues raised by the book. The readers, as Allen Hibbard observes in the preface, may develop the issues further to create a deeper discursive understanding of the complex phenomenon of transnational migrations. Undoubtedly, this book will be of great help to the students and scholars working on Diaspora and Transnationalism. 


\section{WORKS CITED}

LAHIRI, HIMADRI (2019). Diaspora Theory and Transnationalism, Hyderabad: Orient Blackswan.

RUSHDIE, SALMAN (1991). Imaginary Homelands: Essays and Criticism, London: Vintage Books.

SEN, AMARTYA (2003). Identity and Violence: The Illusion of Destiny, London: Penguin.

AuRITRA Munshi is Assistant Professor in English at Raiganj University, West Bengal. He is currently pursuing his $\mathrm{Ph}$.D. His areas of interests are postcolonial studies, diaspora, subaltern studies and gender. 